\title{
Implementasi Nilai Budaya Lokal Sebagai Pengembangan Pariwisata di Kabupaten Buru
}

\author{
Andi Masniati ${ }^{1}$, Susiati ${ }^{1^{*}}$, Kurniati Tuasalamony ${ }^{2}$, Rahma Satya Masna Hatuwe ${ }^{2}$, La \\ Husni Buton ${ }^{3}$, Taufik ${ }^{1}$, Riki Bugis ${ }^{1}$, Risman lye ${ }^{1}$, Harziko ${ }^{1}$ \\ ${ }^{1}$ Fakultas Sastra, Universitas Iqra Buru, Indonesia \\ ${ }^{2}$ Fakultas Ekonomi, Universitas Iqra Buru, Indonesia \\ ${ }^{3}$ Fakultas Agama Islam, Universitas Iqra Buru, Indonesia \\ "Korespondensi: susiatiuniqbu@gmail.com
}

\begin{tabular}{c}
\hline Info Artikel \\
\hline Diterima 19 \\
Desember 2021 \\
Disetujui $24 \mathrm{Mei}$ \\
2021 \\
Dipublikasikan 30 \\
Mei 2021 \\
\hline Keywords: \\
Budaya Lokal, \\
Implementasi, \\
Kabupaten Buru, \\
Pariwisata \\
\hline (c)19 Universitas \\
Muhammadiyah \\
Buton \\
Under the license \\
CC BY-SA 4.0 \\
CC) (i) (2) \\
\hline BY sA
\end{tabular}

\section{Abstract}

This study aims to 1) find out what local cultural values support tourism development in Buru Regency and 2) identify the implementation of local cultural values in supporting tourism development in Buru Regency. This type of research is a qualitative descriptive study with an ethnological approach. The method in this research is field research (field research) with the technique of participatory observation, interview (interview), and study documentation. The places chosen as research locations were Waimiting Village and Kayeli Village. Sources of data from respondents, namely cultural actors, community leaders. The results show what local cultural values support tourism development in Buru Regency, namely from the community belief system, community system, kinship system, technology system, knowledge system, livelihood system, language and 
arts, traditional ceremonies, and prohibition. . From some of these cultural elements, values or norms of practice with local wisdom are born in society, such as artistic behavior, spiritual behavior, economic behavior, political behavior, and other behavior in life and objects as a material entity. The implementation of local cultural values in supporting tourism development in Buru Regency includes four pillars, namely Containing the pillar of Environmental Responsibility; Local Economy Vitality; Cultural Sensitivity; Experiaental Richness.

\section{Pendahuluan}

Pemenuhan sektor unggulan suatu daerah bergantung dari pendekatan dan model kebijakan seperti apa yang ditetapkan oleh Pemerintah Daerah. Salah satu pemenuhan yang dimaksud adalah sektor pariwisata. Kemakmuran masyarakat daerah bergantung dari pemenuhan sektor-sektor, khususnya sektor pariwisata. Masyarakat dapat berpenghasilan jika ada suatu wadah atau area usaha yang secara legal dari Pemerintah Daerah. Pemberdayaan masyarakat merupakan upaya untuk meningkatkan kesadaran, perorangan dan kelompok dalam meningkatkan kualitas hidup, mandiri, serta sejahtera melalui aktivitas kepariwisataan. Undang-undang No. 10 Tahun 2009 terkait Kepariwisataan yang berbunyi pariwisata didefinisikan "berbagai macam kegiatan wisata dan didukung berbagai fasilitas serta layanan yang disediakan oleh masyarakat, pengusaha, pemerintah, dan Pemerintah Daerah". Sementara itu, wisata pula dimaksudkan sebagai "kegiatan perjalanan yang dilakukan oleh seseorang atau sekelompok orang dengan mengunjungi tempat tertentu untuk tujuan rekreasi, pengembangan pribadi atau mempelajari keunikan daya tarik wisata yang dikunjungi dalam jangka waktu sementara" (Haryanto, 2013).

Daya tarik wisata ialah semua hal yang mempunyai bentuk unik, indah, serta memiliki value (nilai) berupa keberanekaragaman kekayaan alam, kultur (budaya), sosial, serta hasil karya manusia yang menjadi tujuan kunjungan wisatawan. Adapun daya tarik wisata yang termaktub dalam (Peraturan Pemerintah Republik Indonesia Nomor 50, 2011) Pasal 14 meliputi a) Daya tarik wisata alam; b) Daya tarik wisata budaya; c) Daya tarik wisata hasil buatan manusia. Pembangunan daya tarik pariwisata dilakukan berdasar pada konsep dan prinsip menaati tata nilai agama, budaya, serta kenetralan antara usaha pengembangan penggunaan sumber daya secara efektif untuk menjadikan daya tarik wisata yang bermutu, memiliki daya saing serta dapat mengembangkan usaha pemeliharaan dan perlindungan terhadap kelestarian dan keberlanjutan sumber dayanya.

Implementasi nilai budaya lokal di Kabupaten Buru diwujudkan sebagai bentuk pengembangan pariwisata yang tersebar hampir di beberapa daerah di Kabupaten Buru, diantaranya Desa Jikumarasa, Desa Rana, Desa Kayeli, Desa Waimiting, dan lain-lain. Ada beberapa bentuk pariwisata yang sedikit berkembang dan maju. Namun, sebahagian besar sedang memerlukan suport dan perhatian penuh pemerintah setempat dan diharapkan pula agar masyarakat menjadi pengelola sekaligus penanggung jawab pelaksanaan pengembangan pariwisata itu.

Menjadi salah satu tujuan wisata inti di Indonesia, Pulau Buru (Kabupaten Buru) mempunyai beberapa hal yang ikut andil dalam hal menarik kunjungan 
wisatawan baik dari dalam maupun mancanegara. Faktor keberanekaragaman suku, budaya, sosial, daerah tujuan wisata menjadi tujuan utama para wisatawan. Faktor aset alam, budaya, serta sejarah yang menjadi ciri khas utama wisata Pulau Buru mampu memberikan jati diri atau identitas yang khas pada pariwisata Pulau Buru. Gladwell dalam (Istiqomah, 2014) mengatakan bahwa nilai lokal ialah salah satu unsur yang berperan penting dalam kesuksesan kepariwisataan.

Masyarakat Buru merupakan suatu komunitas masyarakat adat di Provinsi Maluku. Jika dilihat dalam konteks manusia dan kebudayaan, masyarakat Buru mempunyai budaya (adat kebiasaan) yang menjadi sebuah identitas diri, yaitu kai wait. Kai artinya kakak dan wait artinya adik. Jadi, arti dari kai wait adalah kakak adik. Konsep kai wait sering digunakan dalam berbagai ruang hidup masyarakat Buru. Masyarakat pulau Buru memaknai kai wait sebagai cerminan dari nilai-nilai basudara antarsesama masyarakat. Kabupaten Buru pernah menjadi salah satu daerah konflik, yakni imbas dari konflik sosial pada tahun 1999 di Ambon. Konflik sosial tersebut mengakibatkan terhapusnya nilai hidup basudara (bersaudara) yang telah berakar sejak zaman para leluhur masyarakat Maluku.

Ada beberapa hal yang menjadi dasar pertimbangan sehingga implementasi nilai budaya lokal di Desa Waimiting dan Desa Kayeli menjadi objek penelitian, yakni (1) nilai budaya lokal di Desa Waimiting dan Desa Kayeli belum sepenuhnya terekspos baik secara regional maupun nasional; (2) kurangnya perhatian pemerintah terhadap wisata budaya lokal.

Berdasarkan deskripsi di atas, penelitian ini bertujuan untuk mengetahui nilainilai budaya lokal apa yang mendukung pengembangan pariwisata di Kabupaten Buru dan mengidentifikasi implementasi nilai budaya lokal dalam mendukung pengembangan pariwisata di Kabupaten Buru.

\section{Tinjauan Teori}

\subsection{Konsep Implementasi}

Implementasi merupakan sesuatu yang dilakukan sebagai suatu rancangan yang telah diatur secara sempurna serta terperinci. Implementasi juga lumrahnya dilaksanakan sesudah adanya perencanaan yang matang.

Majone dan Wildavsky dalam (Nurdin, 2002) menyatakan bahwa implementasi adalah perluasan aktivitas yang saling menyesuaikan. Hal yang sama diungkapkan pula oleh Mazmanian dan Sabatier dalam (Wahab, 2001), bahwa implementasi merupakan pelaksana keputusan kebijakan dasar, lumrahnya pada wujud Undang-Undang. Selain itu, dapat pula berwujud dalam berbagai perintah atau keputusan eksekutif yang utama atau badan peradilan lainnya.

\subsection{Nilai Budaya Lokal}

Kebudayaan merupakan semua aktivitas serta daya manusia untuk mengelolah dan mengubah alam (Wiranata, 2002). Geert dalam (Departemen Pendidikan Nasional, 2014), kebudayaan adalah mekanisme kontrol terhadap perilaku sosial anggota masyarakat pendukungnya. Kebudayaan dapat pula dikatakan sebagai ilmu atau pengetahuan manusia tentang aturan, etika, tingkah laku yang mungkin hanya didapat dalam kehidupan bermasyarakat. 
Sama halnya dengan yang diutarakan oleh (Kuntowijoyo, 2006), bahwa point utama kebudayaan memengaruhi dan mengatur unsur-unsur yang terdapat dalam susunan tata hidup manusia seperti tingkah laku. Tingkah laku atau perilaku tersebut merupakan satu kesatuan gejala baik berupa tingkah laku spritual, tingkah laku ekonomi, tingkah laku seni, tingkah laku politik, serta tingkah laku lain dalam kehidupan dan benda-benda sebagai kesatuan material.

\subsection{Pariwisata}

Pariwisata disebut juga sebagai suatu perjalanan dari satu tempat ke tempat lain yang bersifat sementara, dilakukan secara individu ataupun tim sebagai upaya mendapatkan balance atau keserasian serta rasa bahagia dengan lingkungan hidup dalam ukuran ilmu, budaya, sosial, serta alam (Spillane dalam (Wahid, 2015).

Suwantoro dalam (Kurniawan, 2015), hakikat melakukan pariwisata merupakan salah satu rangkaian perbauatan bepergian sementara oleh salah seorang menuju tempat lain di luar tempat tinggalnya. Salah satu faktor dari rasa ingin bepergiannya, yakni karena bermacam kepentingan, baik itu kepentingan ekonomi, sosial, budaya, politik, agama, kesehatan maupun kepentingan lain seperti sekadar ingin tahu, menambah pengalaman serta untuk mencari ilmu.

\section{Metode Penelitian}

\subsection{Jenis Penelitian}

Jenis penelitian dalam penelitian adalah deskriptif kualitatif dengan pendekatan etnologi. Sudaryanto dalam (S. Susiati, 2018a) menyatakan bahwa penelitian kualitatif berfungsi mengidentifikasi, mengklasifikasi, serta menganalisis data yang telah diperoleh, setelah itu mendeskripsikannya dengan bahasa sebagaimana adanya (hal. 116). Dengan demikian pendeskripsian data penelitian ini berupa nilai-nilai budaya lokal yang mendukung pengembangan pariwisata di Kabupaten Buru dan implementasi nilai budaya lokal dalam mendukung pengembangan pariwisata di Kabupaten Buru.

\subsection{Data dan Sumber Data}

Tempat yang dipilih sebagai lokasi penelitian adalah Kabupaten Buru, yakni di Desa Kayeli dan Desa Waimiting. Sumber data dalam penelitian ini adalah dari data primer, yakni pelaku budaya, tokoh masyarakat untuk mendapatkan gambaran mengenai nilai-nilai budaya lokal yang mendukung pengembangan pariwisata berkelanjutan. Data sekunder, yakni dari arsip di Dinas Kebudayaan Kabupaten Buru dan arsip di Kantor Desa. Di beberapa daerah wisata di Kabupaten Buru yang dianggap cikal bakal pengembangan Pariwisata di Kabupaten Buru secara keseluruhan, yaitu di Desa Waimiting dan Desa Kayeli.

\subsection{Metode dan Teknik Pengumpulan Data}

Penelitian ini menggunakan metode observasi nonpartisipatif dimana dalam mengumpulkan data dilakukan dengan tig acara yaitu: 1) pengindraan atau pengamatan langsung dengan menjaga agar peneliti tidak terlibat dalam segala aktivitas objek/responden yang diteliti. Sibarani (S. R. I. Susiati, 2018) menjelaskan bahwa metode observasi nonpartisipatif merupakan salah satu cara peneliti untuk mengambil data dari sebuah fenomena yang diteliti tanpa ikut terlibat dalam segala bentuk aktivitas dari fenomena yang terjadi, dengan kata lain objek diobservasi, 
dideskripsi dan dianalisis berdasarkan fakta yang terjadi; 2) teknik rekam, yaitu digunakan untuk merekam peristiwa-peristiwa yang secara potensial banyak mendeskripsikan tentang nilai-nilai budaya yang ada di Desa Kayeli dan Desa Waimiting; 3) teknik catat, digunakan setelah diperoleh data dari hasil rekaman, data-data berupa nilai-nilai budaya tersebut dicatat selanjutnya diseleksi dan diidentifikasi. Untuk membantu peneliti dalam mengambil data, peneliti menggunakan beberapa instrument seperti catatan lapangan, daftar pertanyaan, alat rekam, dan tabel klasifikasi.

\subsection{Penganalisisan Data}

Dalam menganalisa data, peneliti melaksanakan beberapa tahapan analisis antara lain: 1) seleksi data; 2) klasifikasi data dimana data hasil seleksi diklasifikasi berdasarkan fokus masalah yang terkait dengan nilai-nilai budaya local di desa Waitiming dan desa Kayeli; 3) Analisis data dimana data yang diperoleh dari hasi klasifikasi dianalisis secara mendalam; 4) penarikan kesimpulan terhadap semua fokus masalah sebagai karakteristik nilai-nilai budaya lokal yang akan menjadi aset budaya asli dalam pengembangan pariwisata di Kabupaten Buru.

\section{Pembahasan}

\subsection{Nilai Budaya Lokal Pendukung Pengembangan Pariwisata di Kabupaten Buru}

Budaya lokal di Pulau Buru berupa budaya fisik dan budaya non fisik. Kedua ragam bentuk budaya tersebut mengandung nilai-nilai yang mencerminkan keluhuran masyarakat Pulau Buru. Keberagaman adat istiadat seperti halnya tarian, bahasa, hukum, dan lain sebagainya merupakan aset daerah yang semestinya terus dipertahankan untuk menjadi identitas masyarakat Buru pada khususnya.

Suku Buru merupakan suatu kelompok atau etnis yang dominan tinggal di Pulau Buru. Masyarakat asli Pulau Buru menamakan diri mereka sebagai Gebfuka atau Gebemliar. Menurut artik leksikalnya, makna dari Gebfuka atau Gebemliar adalah Orang Dunia atau Orang Tanah. Masyarakat asli Pulau Buru ketika berkomunikasi menggunakan Bahasa Buru. Bentuk rumah Adat masyarakat asli Pulau Buru, yakni rumah berdinding bambu dan beratapkan alang-alang atau daun kelapa.

Masyarakat asli Pulau Buru bermata pencaharian meramu sagu hutan. Sagu tersebut menjadi makanan pokok dalam keseharian masyarakat asli Pulau Buru. Selain itu, masyarakat asli Pulau Buru membuka ladang dengan ditanami makanan pokok lainnya seperti padi, hotong, jagung, tebu, dan umbi-umbian. Berburu juga merupakan keahlian yang dimiliki oleh masyarakat asli Pulau Buru, misalnya berburu dengan menggunakan senjata tombak dan anjing perburuan.

Garis keturunan masyarakat Pulau Buru adalah patrilineal, yakni ditarik menurut garis laki-laki. Keutuhan hubungan kerabat dalam masyarakat disebut fena. Fena adalah himpunan perkumpulan kekerabatan patrilineal yang disebut etnate atau soa. Setiap fena dikepalai oleh seorang pemimpin yang disebut matlea (gebha) dan wakilnya yang disebut dengan perwies. Matlea dan perwies ditentukan berdasarkan pemilihan oleh anggota fena yang mana setiap tokoh pemimpin mengikuti garis darah pihak laki-laki. Selanjutnya, fena-fena yang ada kemudian membentuk himpunan yang lebih besar yang disebut dengan feulolin 
(fugmolin). Seperti halnya dengan fena, setiap feulin yang terbentuk akan dipilih seorang kepala yang disebut dengan jabu, dan wakilnya hermolon yang mana proses penentuan tokoh pemimpin berdasarkan pemilihan dari setiap wakil dari fena-fena yang ada.

Dalam sistem perkawinan, masyarakat Buru memakai adat eksogami fena, maksudnya bahwa salah seorang mesti menikah atau kawin dengan orang yang berasal dari fena yang berbeda. Seseorang yang akan menjadi suami berkewajiban menyerahkan beberapa mahar kepada pihak keluarga mempelai wanita. Pasca menikah, seorang istri akan diboyong tinggal menetap rumah pihak suami (patriotikal).

Masyarakat Pulau Buru, khusunya yang bertempat tinggal di daerah sekeliling pantai, dominan menganut Islam. Masyarakat Non Muslim mempercayai adanya roh tertinggi, yakni opo geba snulat atau opolastala, sebagai pencipta alam semesta. Selain itu, masyarakat Non Muslim meyakini adanya roh abadi yang mereka sebut dengan esmangin, roh alam yang disebut sanane, roh orang mati yang disebut nituro, dan sebagainya. Keyakinan pada berbagai kekuatan gaib ini diwujudkan dengan pemberian sesajen dan upacara pada waktu-waktu tertentu.

Dalam penelitian ini ada dua desa di Pulau Buru yang akan diidentifikasi terkait budaya lokal yang dapat menjadi pendukung pengembangan pariwisata di Kabupaten Buru. Adapun dua desa tersebut adalah Desa Kaiyeli dan Desa Waimiting.

\section{a. Nilai Budaya Fisik dan Non Fisik di Desa Kayeli dan Desa Waimiting}

Untuk dapat menjadi daerah maju, berkembang, dan berkelanjutan dalam sektor pariwisata, desa Kayeli dan desa Waimiting harus bisa dan mampu melestarikan dan merevitalisasi nilai-nilai budaya dan kearifan lokal lingkungan yang berasal dari budaya fisik dan budaya non fisik masyarakat Kayeli.

Kebudayaan merupakan segala ide dan gagasan dan karya manusia yang didapatkan melalui proses belajar serta segala hasil budi dan karyanya itu. Unsurunsur nilai budaya secara umum terimplementasi dihampir dalam semua system kebudayaan didunia antara lain: 1) system upacara keagamaan; 2) organisasi kemasyarakatan; 3) pengetahuan; 4) Bahasa dan kesenian; 5) pekerjaan; 6) teknologi dan paralatan (Koentjoroningrat dalam (S. Susiati, 2018b).

Kebudayaan juga sifatnya konkret karena merupakan segala bentuk hasil fisik kegiatan atau aktivitas perbuatan atau karya manusia dalam masyarakat (Koenjaraningrat dalam (S. Susiati, 2018b).

\section{1) Sistem Religi}

Masyrakat Kayeli dan Waimiting terdiri dari berbagai etnis atau multicultural. Namun, dalam penelitian ini hanya berfokus pada budaya lokal. Budaya lokal merupakan budaya yang telah mengakar pada masyarakat asli Pulau Buru yang ada di Kayeli dan di Waimiting.

Sebelum mengenal agama, masyarakat asli Pulau Buru di Desa Kayeli menganut roh-roh para leluhur atau nenek moyang mereka (animisme). Animisme merupakan suatu wujud agama yang berlandaskan pada suatu kepercayaan bahwa alam serta sekeliling tempat tinggal manusia dihuni oleh berbagai macam roh, serta terdapat pula berbagai macam aktivitas keagamaan dalam memuja roh- 
roh tersebut. Eksistensi roh-roh bagi masyarakat asli Pulau Buru di Desa Kayeli mendapat tempat yang paling utama dalam kehidupan mereka sehingga mereka jadikan objek penghormatan dan penyembahan seperti dilakukan dalam berbagai upacara, doa, sajian korban, dan sebagainya. Sistem kepercayaan tersebut bukan hanya berlaku pada masyrakat asli Pulau Buru di Desa Kayeli saja tetapi secara umum pada masyarakat asli Pulau Buru atau biasa disebut dengan Geba Bupolo (anokton).

Secara umum, Geba Bupolo dalam menjalankan atau melaksanakan keyakinan terhadap para leluhur membagi ruang di wilayahnya menjadi tiga bagian, yakni 1) wilayah yang dilindungi karena memiliki nilai kekeramatannya, seperti Gunung Date (Kaku Date), daerah keramat di hutan primer (Koin Lalen), serta Danau Rana (Rana Waekolo); 2) kawasan yang diusahakan meliputi pemukiman penduduk (bumalolin dan fenalalen), kebun (bawa), meramu (mua lalen) atau berburu (neten embalit), hutan kayu putih (galen lalen), serta area memancing (wae lalen); 3) kawasan atau area yang tidak diusahakan, seperti bekas perkebunan (Wasi Lalen) dan padang ilalang (mebet lalen). Pembagian kawasan tersebut erat hubungannya dengan keyakinan atau kepercayaan tradisional dan kosmologi geba bupolo. Hal tersebut berlaku karena mereka percaya bahwa asal usul mereka berhubungan dengan alam semesta dan mereka hidup berkat kekayaan yang dimiliki oleh alam seperti tanah, air, dan gunung. Menurut kepercayaan geba bupolo, nenek moyang mereka berasal dari gunung. Danau rana sebagai air dan gunung date sebagai gunung. Oleh sebab itu, gunung date dan danau rana merupakan tempat yang disakralkan dan dikeramatkan, banyak ketentuan dan peraturan yang harus dijaga dan tidak boleh dilanggar, sehingga untuk mendatangi atau berkunjung ke tempat tersebut harus minta izin atau harus melalui prosesi doa dari kepala Soa (kepala adat).

Geba bupolo juga lazim menyembah roh para leluhur dengan cara menyimpan barang-barang milik leluhur seperti pakaian adat, lestari, atau bendabenda asing yang disimpan di tempat khusus dan aman. Selain itu, pepohonan yang besar dan rindang diyakini juga sebagai tempat tinggal roh-roh para leluhur mereka. Orang-orang asli Pulau Buru pada umumnya percaya bahwa dalam setiap daerah atau desa, berbagai tempat tertentu, sungai mempunyai penamaan asli atau penamaan rahasia ( $\mathrm{Na}$ Leit) pemberian dari para leluhur mereka. Nama-nama tersebut bersifat rahasia sehingga tidak boleh disebut sembarangan, diperbolehkan kecuali pada waktu-waktu tertentu saja. Seperti, ketika mengalami bencana atau kesusahan maka kepala soa atau kepala adat atau orang pintar (dukun) yang mengetahui nama-nama tersebut akan dipanggil untuk menyebut dengan tepat.

Latar belakang masukanya agama atau keyakinan didesa Waitiming dan Kayeli ditandai dengan kelompok pendatang, sehingga secara bertahap penduduk asli memeluk keyakinan kaum pendatang yaitu Islam dan Kristen. Keyakinan ini semakin terjaga dengan adanya fasilitas peribadatan seperti masjid dan gereja untuk menjamin aktivitas peribadatan berlangsung dengan lancar. Di Kayeli sendiri masyarakat asli Pulau Buru sudah menganut agama Islam dan ada beberapa yang menganut agama Kristen seperti di Dusun Lokasi.

Sementara, di Desa Waimiting seratus persen masyarakat menganut agama Islam dan setiap kegiatan mereka selalu bersentuhan dengan norma-norma agama Islam. Masyarakat Waimiting masih menjalankan pantang larang yang 
ditetapkan oleh para leluhur mereka, seperti tidak diperbolehkan membuang hajat besar di lingkungan perkampungan serta dilarang membuat jamban di dalam rumah atau di halaman rumah.

\section{2) Sistem Kekerabatan}

Geba bupolo mempunyai sistem kekerabatan yang berorientasi pada pola perkawinan patrilinear yang disertai dengan pola patrilokal, yakni tempat tinggal berpusat pada wilayah turunan bapak atau ayah. Kesatuan dari kekerabatan yang memiliki nilai lebih tinggi adalah matarumah atau fam. Matarumah (fam) adalah sebuah wujud kelompok yang bersifat patrilinear. Matarumah adalah kesatuan lakilaki dan perempuan yang belum menikah dan istri-istri dari laki-laki yang sudah menikah. Artinya, matarumah merupakan suatu klen kecil dari patrilineal. Matarumah eksistensinya dianggap penting dalam hal mengatur perkawinan warganya secara eksogami serta untuk megatur segala tanah dati, yakni tanah miliki kerabat patrilineal. Perkawinan bersifak exogami maksudnya seseorang mesti kawin dengan orang di luar klennya. Tradisi exogami dapat dibagi ke dalam beberapa ranah, yakni 1) exogami keluarga inti; 2) exogami marga (larangan untuk kawin dengan sesama marga); 3) exogami desa (larangan untuk kawin dengan warga desa, dan lain-lain). Selai itu, adapula kesatuan yang lebih besar dari matarumah dan bersifat bilateral, yakni kindred atau family. Family merupakan kesatuan kekerabatan yang ada di sekeliling individu yang terdiri dari para warga yang masih hidup dari matarumah asli, yakni seluruh keturunan dari ke empat nenek moyang.

Jenis-jenis perkawinan adat suku Buru, yaitu

\section{a) Kawin Biasa (Maso Minta)}

Kawin maso minta memiliki maksud keluarga laki-laki datang melamar seorang anak perempuan yang berasal dari keluarga lain untuk dijadikan sebagai istri oleh anak mereka. Dalam tradisi maso minta tersebut para keluarga membcarakan beberapa perihal seperti harta atau barang, jika hal yang dibicarakan tersebut menemui kesepakatan atau sudah terpenuhi oleh pihak lakilaki maka perempuan dapat dibawa pulang. Berikut ini tahapan dalam perkawinan maso minta: 1) Humaslaun, yakni pihak dari laki-laki datang ke rumah pihak perempuan setelah itu pihak perempuan membuka pintu yang diwakili oleh juru bicara sambal mengucapkan bahasa adat yang bermaksud mempersilahkan pihak laki-laki masuk ke dalam rumah. Tahapan ini bertujuan supaya dalam mengarungi biduk rumah tangga selalu lancar dan tidak ada gangguan atau hambatan karena sudah didahului dengan adat. Dari pihak laki-laki membawa tanda jadi, yakni berupa uang yang diisi dalam sebuah amplop atau sirih pinang (fua lamon) yang disimpan di atas sebuah piring. Buka pintu biasa disebut oleh geba bupolo sebagai fua lamon atau adat skota sufen; 2) Harta Gandong biasa disebut dengan harta orangtua, yakni prosesi di mana setelah diterima dalam rumah keluarga perempuan, maka keluarga dari kedua belah pihak duduk bersama membahas harta gandong, harta fena (harta soa), dan kain putih yang disangkut di atas baileo atau rumah pihak perempuan (kampisut). 3) Jiwa filin biasa disebut dengan bayar jiwa, yakni ketika pihak keluarga laki-laki membayar jiwa si perempuan dengan menggunakan kain putih dan uang. Hal ini bermaksud karena jiwa dalam soa itu telah keluar dan masuk marga orang lain/suaminya. Dengan diterimanya bayaran tersebut oleh pihak perempuan maka secara langsung anak perempuan itu 
diterima dalam keluarga laki-laki. Bentuk proses pembayaran ini, yakni kepala soa dari pihak perempuan memegang tangan kepala soa laki-laki sebagai simbol atau tanda. Saat si perempuan tiba di kediaman laki-laki, si perempuan tersebut diterima dengan kain putih (kakitanata). Diujung kain terdapat tikar yang dibentangkan secara terbalik, saat perempuan akan memasuki rumah si laki-laki tikar tersebut dibalik dan si perempuan berjalan di atasnya dengan disertai dengan kapata-kapata yang mengandung maksud atau makna balik fam atau marga (kelili leit), yang secara umum memiliki arti bahwa masuknya marga laki-laki; 4) Kelili Leit (balik fam) merupakan tahap yang mana marga atau fam dari mempelai perempuan diganti ke dalam marga suami; 5) Sigluti, yakni orangtua serta pihak keluarga perempuan membawa atau mengantar mempelai perempuan ke rumah mempelai lelaki yang lazim disebut dengan fina febut (perempuan baru) dan mereka membawa barang-barang berupa peralatan rumah tangga yang berjumlah 150 buah diperuntukkan bagi anak perawan sedangkan untuk janda barangbarangnya berjumlah 50 buah.

b) Kawin Panjar

Kawin pinjar adalah perkawinan yang berlaku ketika seorang anak perempuan masih di dalam kandungan si lbu telah dilamar oleh pihak laki-laki untuk dijadikan istri. Jika rangkaian lamaran dari pihak laki-laki tersebut diterima oleh pihak perempuan, maka kewajiban pihak laki-laki adalah membayar setengah dari seluruh harta yang diminta oleh pihak perempuan. Jika anak perempuan tersebut lahir, anak tersebut akan diambil oleh pihak laki-laki untuk mereka rawat hingga besar dan akan dinikahkan dengan si laki-laki jika sudah memasuki usia matang. Dalam proses pernikahan tersebut keluarga pihak laki-laki wajib melunasi sisa utang (berupa harta) yang belum terbayarkan kepada pihak perempuan.

c) Kawin Lari

Kawin lari adalah suatu sistem perkawinan yang biasa terjadi di lingkungan masyarakat. Hal tersebut disebabkan biasanya masyarakat Buru lebih menyukai proses yang cepat atau lebih memilih jalan singkat. Mereka lakukan itu untuk mengindari proses perundingan serta upacara. Kawin lari bagi masyarakat dianggap kurang patut untuk dilakukan dan kurang mendapatkan respon positif oleh kerabat pihak perempuan. Sebaliknya, keluarga pihak lelaki, kawin lari lebih disukai dengan perspektif bahwa seorang lelaki mau menghindari rasa kecewa ketika pihak perempuan menolak serta menghindari rasa malu dari para keluarga lelaki tersebut.

d) Kawin Marwang

Kawin marwang dilaksanakan ketika harta yang diminta oleh keluarga perempuan tidak dipenuhi oleh keluarga lelaki. Konsekuensinya, lelaki tersebut harus tinggal serta bekerja di rumah perempuan hingga lelaki tersebut dapat membayar harta yang telah ditentukan oleh pihak perempuan. Lelaki harus dapat menyesuaikan dengan aktivitas sehar-hari pihak perempuan, misalnya harus membantu mertuanya berkebun, menangkap ikan, memperbaiki rumah, serta mencari kayu bakar. Ketika lelaki tersebut tidak mampu membayar harta maka semua bantuan dan jasa yang telah ia berikan telah dianggap sudah melunasi maharnya. 


\section{3) Sistem Pengetahuan}

Fungsi sistem pengetahuan dalam kehidupan manusia adalah tepenuhinya rasa keingintahuan manusia terhadap suatu ilmu yang ada di sekeliling mereka (Sahib, 2019). Manusia bisa memenuhi dan mengelola kebutuhan hidup melalui pengetahuan yang dimilikinya. Berikut ini beberapa sistem pengetahuan masyarakat asli Pulau Buru yang ada di Desa Kayeli dan Desa Waimiting.

\section{a) Pengetahuan tentang Alam}

Pengetahuan masyarakat tentang alam sangat tinggi baik di laut maupun di darat. Masyarakat asli Pulau Buru memiliki pengetahuan tentang alam di laut dengan bisa menebak musim dan juga gejala alam. Mereka masih menggunakan arah angin untuk menentukan suatu musim. Pengetahuan yang dimiliki tersebut diperoleh secara langsung dari kebiasaan mereka setiap hari. Selain itu, di darat mereka dapat membedakan secara langsung musim hujan dan musim paceklik misalnya pada bulan apa saja akan berlaku musim hujan dan pada bulan berapa saja musim paceklik akan melanda. Pengetahuan yang mereka peroleh selain dari pengalaman, mereka mendapat pula ilmu dari para leluhur mereka.

\section{b) Pengetahuan tentang Tumbuhan}

Pengetahuan masyarakat juga tertuju pada pengetahuan mereka tentang tumbuhan. Masyarakat asli Pulau Buru tahu akan jenis dan tumbuhan yang dapat dijadikan obat atau ramuan yang kadang-kadang belum diketahui oleh para ahli medis di seluruh dunia. Misalnya, ada salah satu tumbuhan yang mereka namakan dengan daun gatal. Tunbuhan tersebut mereka gunakan untuk mengobati rasa pegal-pegal di badan. Selain itu, ada pula pohon kayu putih yang sekarang sudah familiar hingga ke seluruh negara. Pohon kayu putih sudah dipakai oleh para leluhur masyarakat asli Pulau Buru dari zaman dulu. Produksi kayu putih sekarang telah menjadi mata pencaharian masyarakat Pulau Buru.

\section{c) Pengetahuan tentang Binatang}

Masyarakat asli Pulau Buru juga sangat mengenali berbagai jenis binatang karena salah satu mata pencaharian mereka adalah berburu. Mereka bisa mengetahui musim-musim berburu. Semua pengetahuan ini mereka peroleh dari kebiasaan rutin mereka, yakni berburu. Mereka pula dapat membedakan binatang yang buas dan binatang yang dapat dikonsumsi oleh manusia. Mereka pun bisa mengetahui cara-cara mendapatkan binatang buruan dengan mudah dan aman.

d) Pengetahuan tentang Tata Laku (Tingkah Laku)

Pengetahuan masyarakat asli Pulau Buru tentang sifat dan perilaku manusia mencakup deskripsi manusia dalam bersikap, bertingkah, dengan mematuhi segala norma atau nilai, aturan, hukum adat, hukum kenegaraan yang berlaku.

Di dalam masyarakat khususnya masyarakat desa Kayeli dan masyarakat desa Waimiting selalu menerapkan kebersamaan, kegotongroyongan, saling menghargai, ringan tangan, dan saling menghormati. Seperti, jika ada yang mengalami kedukaan maka masyarakat lain datang dengan memberikan bantuan berupa barang atau uang. Begitu pula ketika ada acara pernikahan, para masyarakat datang membantu pihak yang melaksanakan acara pernikahan.

e) Pengetahuan tentang Ruang dan Waktu 
Pengetahuan masyarakat Kayeli dan masyarakat Desa Waimiting tentang ruang dan waktu dipakai untuk menghitung, mengukur, mereka serta menghitung hari baik, yakni hari baik dalam pernikahan, hari baik ketika akan bepergian, dan lain-lain. Selain itu, mereka keberadaan orang yang hilang atau orang yang terbunuh. Yang berperan dalam penentuan hari baik ini kepala soa dan dukun. Kebiasaan ini masih melekat sampai sekarang di tengah-tengah masyarakat Pulau Buru.

\section{4) Sistem Teknologi}

Masyarakat Buru dalam sistem teknologi masih menggunakan alat-alat tradisional tetapi mereka juga sudah menyesuaikan dengan teknologi modern. Mereka menggunakannya bergantung kebutuhannya. Suatu kebutuhan alat-alat atau perlengkapan yang dipakai suatu masyarakat bergantung dari kebiasaan mereka mengolah dan meramu makanan keseharian mereka. Misalnya, masyarakat Buru mempunyai makanan khas yakni papeda, kasoami, sagu lempeng, dan sebagainya yang kesemuanya itu memiliki alat khusus untuk mengolah makanan tersebut. Sehingga, dapat disimpulkan bahwa teknologi pada suatu daerah dapat berbeda-beda karena cara atau pemikiran manusia tidak selalu sama. Terdapat teknologi dalam mengolah daun kayu putih menjadi minyak kayu putih.

Adapula alat-alat tradisional yang masih digunakan oleh masyarakat Pulau Buru secara umum, seperi ketika mereka melaut mesyarakat sering menggunakan perahu, jaring, dan kail. Namun, dengan berkembangnya ilmu teknologi masyarakat pun sudah ikut terseret dengan arus globalisasi yang sekarang dapat sering dilihat ketika mereka mencari ikan sudah menggunakan bobong dengan bantuan mesin sehingga penangkapan ikan lebih mudah dan hasilnya yang didapat banyak.

Sementara, ketika masyarakat berburu binatang di hutan, alat yang mereka pakai adalah slibit (pisau kecil yang diikat di ujung bambu atau kayu), tombak, parang, senapan angin, bambu runcing, dudeso (perangkap yang terbuat dari tali atau kawat). Dudeso memiliki tiga jenis, yakni dudeso leher, dudeso kaki, dan sungga (terbuat dari bamboo runcing yang ditajamkan dan ditancapkan di atas tanah dalam jumlah banyak, tingginya sekitar $50 \mathrm{~cm}$ ).

Makanan tradisional masyarakat Buru adalah padi hotong, padi, patatas (ubi jalar), kasbi (ubi kayu), kasoami (olahan kasbi yang dikukus). Makanan tradisional ini masih menjadi makanan pokok masyarakat geba bupolo maupun geba misnit.

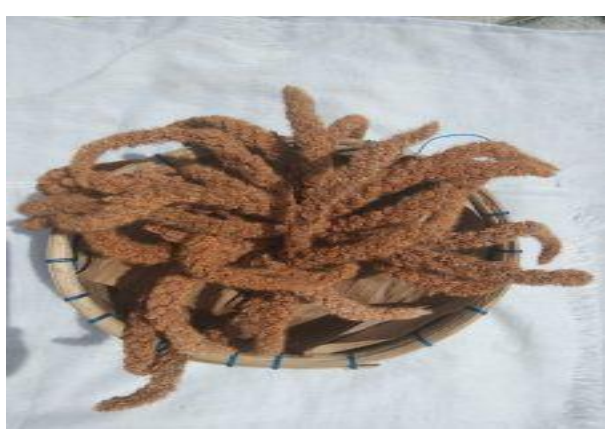

(a)

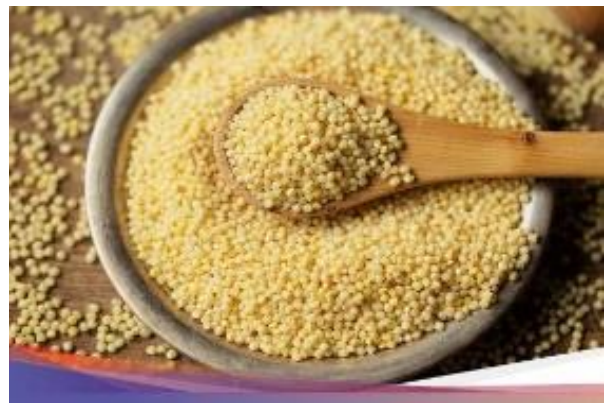

(b) 


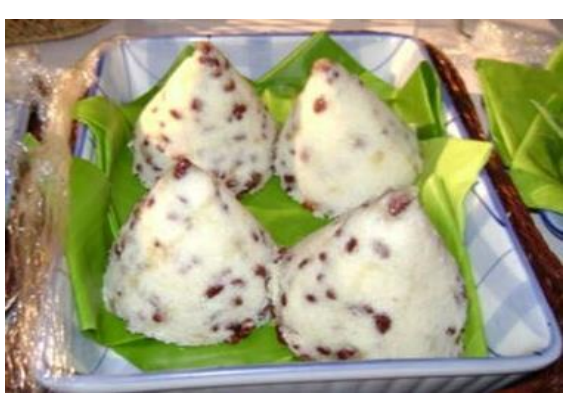

(c)

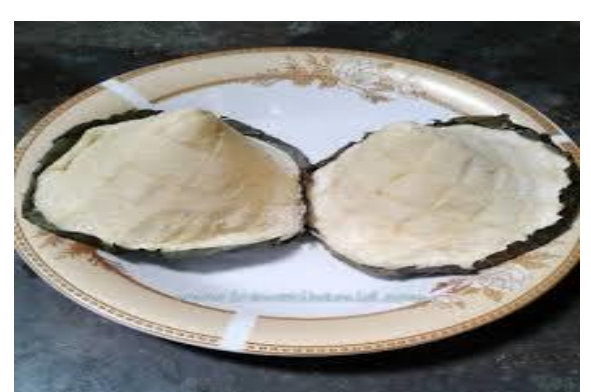

(d)

Gambar 1. Padi Hotong (1); Bulir Hotong (2); Kasoami Gula (3); Kasoami (4)

Tempat berlindung ataupun rumah jika di lihat sekarang lebih bergaya modern. Hal tersebut karena telah dipengaruhi oleh gaya rumah para Geba Misnit. Namun, masih dapat ditemukan beberapa bentuk rumah asli masyarakat Buru (Geba Bupolo) yakni yang ada di bagian pegunungan atau bagian pedalaman Pulau Buru. Bentuk pemukiman masyarakat asli Pulau Buru, yakni rumah papan beratapkan daun sagu atau daun kelapa yang dianyam.

Pakaian masyarakat Pulau Buru adalah kebaya atau kemeja. Bentuk pakaian tersebut lambat laun bergeser ke pakaian modern, pakaian asli masyarakat Pulau Buru dapat dilihat jika ada upacara adat. Para ina-ina dan tete-tete, akan mengenakan kebaya serta kemeja saat upacara adat berlangsung.

Ifutin atau selendang kepala atau lestari merupakan pakaian adat masyarakat asli Pulau Buru. Cara pemakaiannya pun tidak boleh sembarang bentuk karena bagi masyarakat asli Pulau Buru penggunaan lestari atau ifutin dapat menentukan jati diri atau identitas si pemakainya. Misalnya, kepala soa bentuk ifutin yang dipakainya harus berbeda dengan masyarakat biasa. Jadi, ada bentuk khusus untuk para kepala soa. Kepala soa disebut juga dengan pimpinan marga, yakni setiap dusun memiliki kepala soa.

\section{5) Sistem Kemasyarakan}

Sistem kemasyarakatan masyarakat asli Pulau Buru khususnya masyarakat desa Kayeli dan Desa Wimiting terikat oleh suatu aturan adat yang tiap dusun dikepalai oleh soa yang mereka sebut dengan kepala soa. Masyarakat sangat menghormati ketetapan adat. Adapun bentuk sistem kekerabatan pada masyarakat Kayeli dan Waimiting, yakni saling tolong menolong, hidup rukun antarwarga, menolong dan memberi bantuan kepada pihak yang memerlukan pertolongan. Hal tersebut terlihat, jika ada warga yang mendapat hasil buruan ataupun hasil melaut maka mereka akan memanggil para tetangga untuk menyantap hasil buruan bersama-sama. Kebersamaan ini merupakan prinsip yang mereka dapat dari para leluhur mereka bahwa masyarakat Buru harus selalu menumbuhkan sikap kai wait. Kai artinya kakak dan wait artinya adik. Arti secara umum kai wait merupakan persaudaraan (basudara), sehingga prinsip tersebut tercermin dalam kehidupan masyarakat Buru di manapun mereka berada.

6) Sistem mata pencaharian

Sistem mata pencaharian masyarakat Buru khususnya masyarakat Kayeli dan masyarakat Waimiting adalah berladang, nelayan, bertani, berburu, penyuling 
minyak kayu putih. Mata pencaharian tersebut sudah ada sejak zaman dulu yang diterapkan oleh nenek moyang mereka. Meskipun sekarang sudah banyak bermunculan mata pencaharian yang lebih modern seperti guru, pekerja swasta, penambang emas tetapi masyarakat tidak meninggalkan mata pencaharian tradisional mereka.

Dalam pelaksanaan sistem mata pencaharian masyarakat asli Pulau Buru selalu percaya bahwa kemakmuran yang mereka dapatkan dalam kehidupan mereka berkat restu dari dato leluhur. Sehingga ada simbol-simbol yang mereka buat sebagai penghormatan mereka pada alam dan dato leluhur. Misalnya saja ketika sudah masuk musim bercocok tanam mereka membuat namlahi. Namlahi merupakan simbol doa pelindung yang dipersembahkan kepada dato leluhur. Namlahi akan terus dipasang dan jadi pelindung ladang mereka.

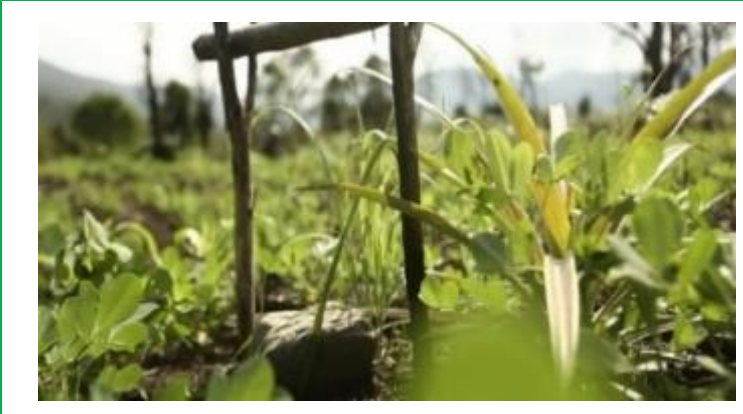

(a)

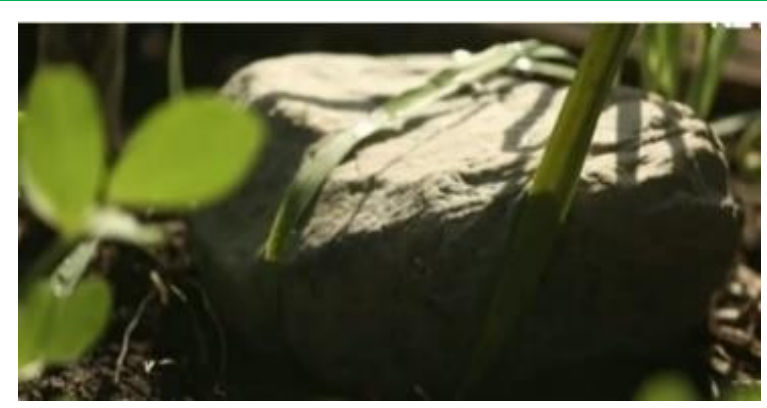

(b)

Gambar 2. (a) dan (b) merupakan bentuk Namlahi yaitu symbol pelindung saat bercocok tanam

\section{7) Bahasa}

Bahasa merupakan sebuah unsur kebudayaan yang dipakai untuk berkomunikasim berinteraksi antara masyarakat (Suherman, 2018; Mansyur, 2020). Masyarakat Kayeli sebagian masih menggunakan bahasa daerah Buru dalam berkomunikasi tetapi adapula yang menggunakan bahasa Melayu Ambon dalam berinteraksi dengan sesama masyarakat asli pulau Buru atau dengan masyarakat pendatang. Masyarakat asli Pulau Buru sebagian multilingualisme, artinya mereka menguasai lebih dari dua bahasa, bahasa daerah, bahasa Melayu Ambon, dan bahasa Indonesia. Namun, yang dominan nampak digunakan oleh masyarakat Kayeli dan masyarakat Waimiting ketika berkomunikasi adalah bahasa Melayu Ambon.

\section{8) Kesenian, Upacara Adat, Pantang Larang}

Ada berbagai macam kesenian yang dimiliki oleh masyarakat Geba Bupolo. Kesenian-kesenian tersebut merupakan kesenian yang diciptakan oleh para leluhur mereka. Konteks kesenian selalu mencerminkan kehidupan masyarakat asli Pulau Buru pada masa lampau. Seperti tarian dan alat musik. Ada berbagai tarian lokal Pulau Buru yang hingga sekarang masih lestari misalnya tarian Sawat biasa oleh masyarakat disebut dengan Tari Sawat Buru, tarian Cakalele, tarian Toloprari Damang Fafu, tarian Gendang Perahu, dan tarian Saureka-Reka. Selain itu, pada zaman sekarang seiring perkembangan pemikiran dan meningkatnya kreatifitas masyarakat pulau Buru dari sebuah sejarah tentang asal usul tanaman 
Hotong di tanah Fuka Bupolo (Pulau Buru) menandai dan terciptanya tarian yang bernama Boki Feten.

Tari Sawat Pulau Buru adalah salah satu aset budaya yang bersifat arif dan telah menyatu bersama keberagaman suku atau etnis budaya masyarakat masyarakat Pulau Buru. Tarian Sawat digunakan oleh masyarakat Buru sebagai tarian pergaulan. Makna pergaulan di sini karena setiap tarian ini diperagakan oleh para penari diharapkan tetamu juga ikut menari tari Sawat. Tarian Sawat merupakan gabungan budaya Maluku dan budaya Timur Tengah. Ratusan tahun yang lalu, bangsa Arab muncul untuk menyebarkan agama Islam di Maluku, setelah itu berlakulah penggabungan budaya khususnya dalam ranah musik seperti pada beberapa alat musik tari Sawat, yakni gendang (rebana) dan seruling. Sementara itu, tarian Cakalele mendeskripsikan jiwa perkasa orang Maluku. Tari ini diperakan oleh beberapa pria dewasa sembari memegang parang dan Salawaku (Perisai). Tarian cakalele merupakan tarian perang. Tarian cakalele sering ditampilkan sebagai tarian penyambutan para tamu. Sehingga para tamu yang disambut dengan tarian cakalele harus merasa bangga karena prajurit terbaiklah yang menyambut mereka di dusun. Tarian Saureka-reka merupakan tarian dengan memakai pelepah pohon sagu. Tarian ini diperagakan oleh enam orang gadis. Tarian ini membutuhkan ketepatan dan kecepatan sembari diiringi musik.

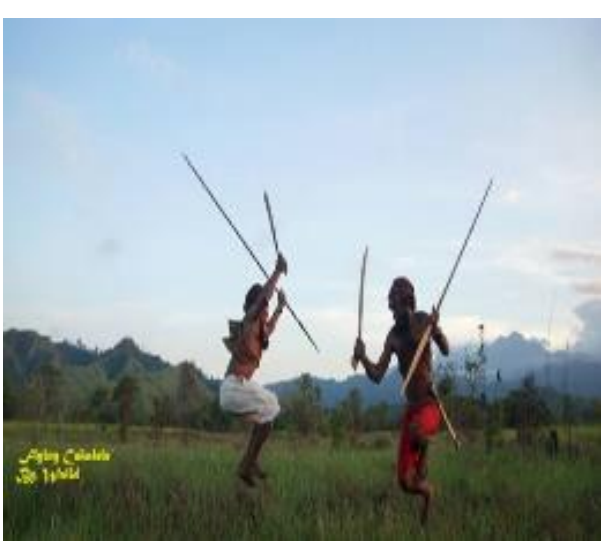

(a)

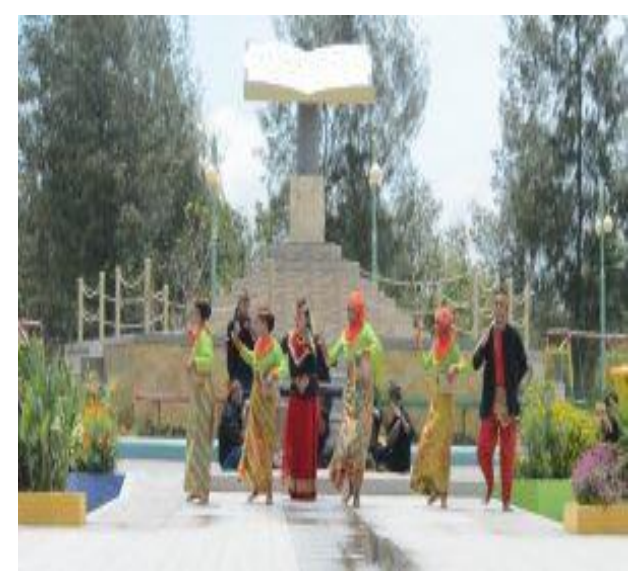

(c)

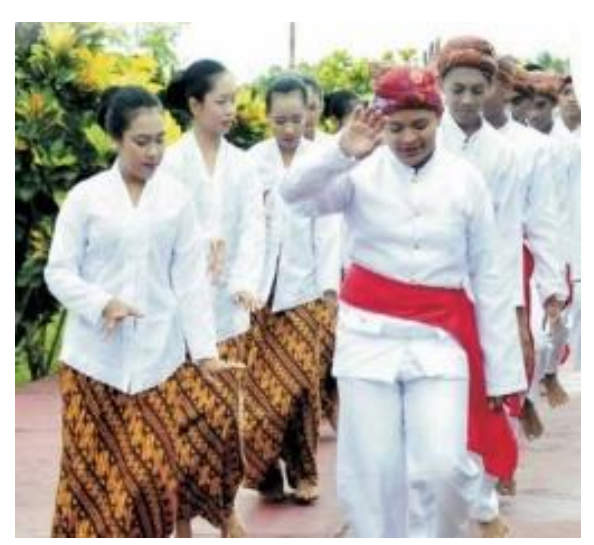

(b)

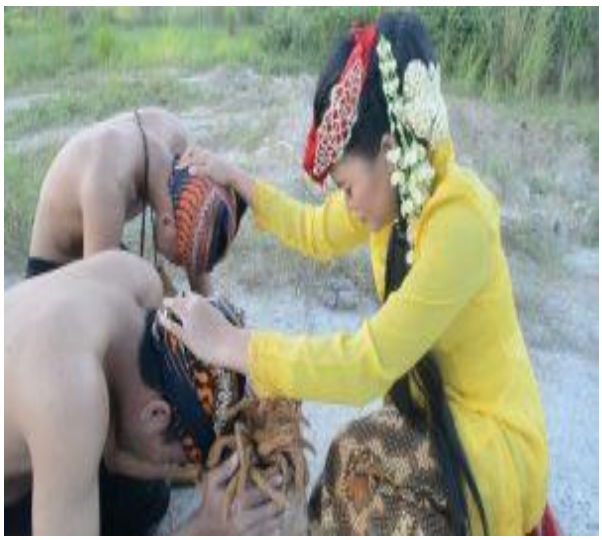

(d)

Gambar 3. Tarian Cakalele (a); Tarian Sawat (b); Tarian Boki Feten (c) dan (d) 
Tari Boki Feten mencerminkan keadaan dan pribadi masyarakat pulau Buru. Sekarang ini gambaran kehidupan para leluhur dalam menghormati kekayaan yang dimiliki oleh bumi bupolo dapat kita melihatnya dalam tarian Boki Feten.

Pada petuanan Kayeli terdapat salah satu hukum adat, yakni pengangkatan dengan diadakannya ritual, yakni bertanya kepada dato leluhur opolastala dalam rangka menetapkan pengangkatan raja maka diadakannya perburuan di hutan. Barang siapa yang mendapatkan binatang buruan sangat banyak, maka dialah yang akan diangkat menjadi raja. Noro Pitu yang mempunyai hak untuk mengangkat raja, yakni kepala soa yang berasal dari Kaiely yang telah ditetapkan untuk proses pelantikan. Tempat berkumpul mereka di rumah tujuh (7) soa di Waeflan. Kemudian itu, para kepala soa mulai melakukan pemotongan babi, selanjutnya melaksanakan berbagai ritual. Ritual-ritual pembentukan kerajaan Kaiely tersebut sudah ada sejak dahulu dan pelaksanaannya telah turun temurun, proses tersebut dinamakan dengan smaket, setelah itu kepala soa gewagit menuturkan bahwa "inilah raja kita dan kemudian diikuti oleh kepala soa yang lain".

Ritual tradisi penobatan raja di atas hampir sama dengan penobatan raja pada tiga (3) petuanan adat yang tersebar di Kepulauan Buru.

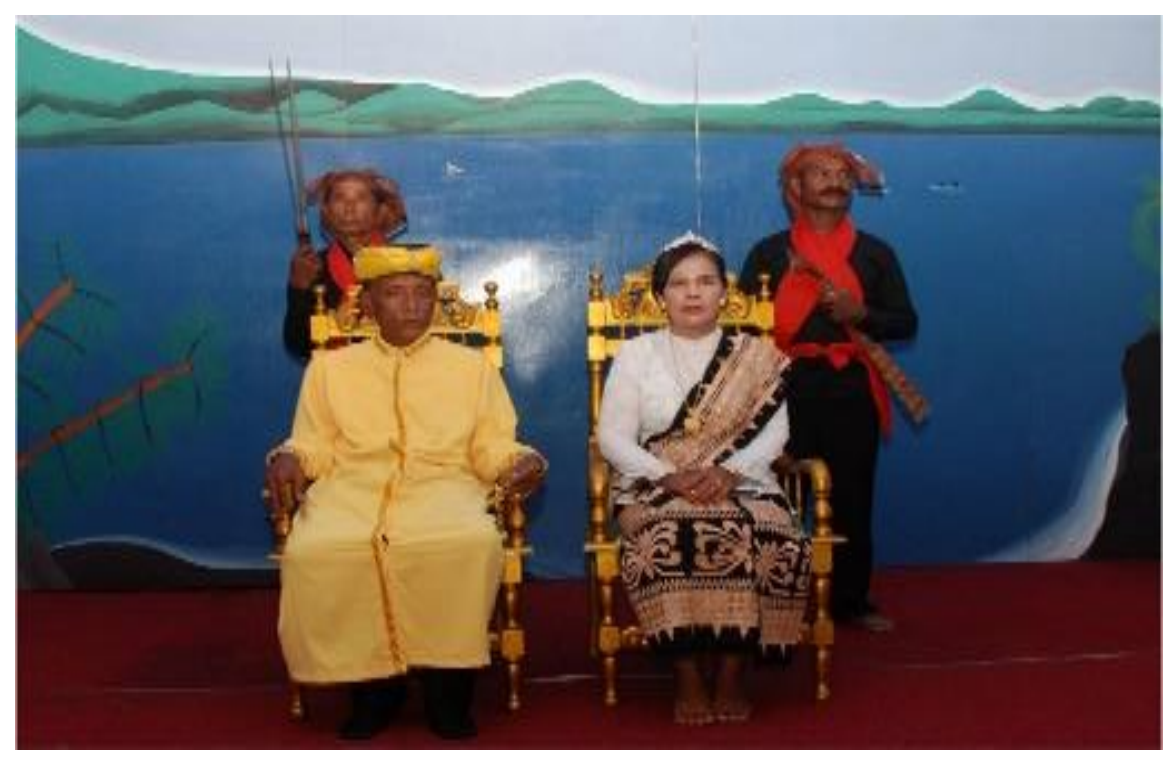

Gambar 4. Pengangkatan dan Penobatan Raja

Pantang larang merupakan sesuatu yang dipercaya oleh masyarakat Kayeli dan masyarakat Waimiting. Di Desa Waimiting terikat dengan pantang larang yang jika dilanggar akan mendatangkan bala (bencana). Bencana tersebut dapat berupa munculnya sosok binatang buas ke dalam kampong atau dalam bentuk lain. Pantang larang di Desa Waimiting, yakni tidak diperbolehkan membuat kakus atau jamban (tempat buang hajat besar), dilarang mengadakan acara joget di dalam kampong, dilarang menyantap makanan di rumah duka, dan lain-lain. Ketetapan ini sudah ada sejak zaman dulu. Tradisi ini merupakan hasil cipta, rasa, dan karsa dato leluhur mereka.

\subsection{Implementasi Nilai Budaya Lokal Terhadap Pengembangan Pariwisata}

Jika ingin suatu Desa Wisata dapat maju, berkembang, serta berkelanjutan, maka mesti dapat merevitalisasi dan membuat lestari nilai-nilai budaya lokal 
(Rahman, 2018) baik itu berkaitan dengan kearifan lokal, kosmologi, serta falsafah hidup geba bupolo. Secara khusus, nilai-nilai yang tetap lestari dalam budayabudaya lokal di lingkungan masyarakat adalah kai wait (basudara), loyalitas pada hokum adat, saling menghormati, saling membantu, berpegang teguh, cinta lingkungan, menghargai hidup apa adanya, jangan serakah, dan sebagainya.

Perlu diketahui bahwa umumnya implementasi dari berbagai nilai budaya lokal yang menjadi pendukung suatu pengembangan Desa Wisata di Kabupaten Buru dimanifestasi ke dalam berbagai bentuk kegiatan yang disajikan kepada para wisatawan. Ada beberapa macam kegiatan atau atraksi yang ditampilkan, yakni

\section{a. Tarian Cakalele}

Tarian cakalele merupakan tarian perang. Tarian ini dilakukan ketika menyambut para tamu atau pengunjung. Makna dari tarian cakalele adalah memberi perlindungan kepada para tamu. Sehingga para tamu yang disambut dengan tarian cakalele harus merasa bangga karena prajurit terbaiklah yang menyambut mereka. Setelah para tamu disambut dengan tarian cakalele, para tamu langsung disuguhkan dengan sirih pinang. Umumnya, pementasan tarian ini mendeskripsikan terdapatnya suatu asas pengembangan local economic vitality, pengkayaan jenis pementasan/atraksi (experiental rishness), cultural sensitivity, dan environmental responsibility.

\section{b. Tarian Sawat serta tabuhan tifa dan totobuang}

Tarian sawat yang diiringi dengan tabuhan tifa dan totobuang sebagai manifestasi utama membangun tali pergaulan, persaudaraan, dan keakraban dengan para pengunjung. Ketika para penari menarikan tarian sawat, para pengunjung pun diikutsertakan untuk menari sawat. Hal tersebut dilakukan karena fungsi tari sawat adalah mengikat pergaulan sesama. Secara umum jenis tarian ini tertuju pada suatu prinsip pengembangan ekonomi lokal (local economic vitality), pengkayaan, jenis tarian (experiarntal richness), cultural sensitivity, dan environmental responsibility.

Di samping jenis budaya lokal yang sifatnya hampir serupa antara desa Kayeli dengan desa Waimiting, masing-masing desa tersebut dapat menyajikan jenis atraksi budaya unggulan yang menjadi ciri khas atau potensi unggulan dari desa-desa tersebut. Berbagai jenis atraksi ini tentu sangat terkait dengan kondisi alam dan geografis daerah tersebut.

Desa Kayeli dan desa Waimiting berada pada wilayah yang sama, yakni Kabupaten Buru meskipun itu tiap-tiap desa memiliki potensi unggulan dalam bidang budaya dengan corak yang berbeda. Misalmya, di Desa Kayeli para pengunjung akan disuguhkan dengan berbagai corak kehidupan masyarakat asli Pulau Buru, dari bentuk rumah atau pemukiman pun masih didapatkan hunian masyarakat asli pada zaman dulu, kehidupan masyarakat dalam bercocok tanam, berburu pun dapat dengan mudah didapati di Desa Kayeli. Dari segi upacara adat, di Desa Kayeli merupakan salah satu peradaban masyarakat asli Pulau Buru sehingga di Kayeli ada didapati upacara pengangkatan dan penobatan raja Kayeli. Berbagai situs sejarah juga menambah pesona desa Kayeli. Selain itu, terdapat pula kepercayaan-kepercayaan tentang hal ghaib atau mitos dan kosmologi masyarakat yang tinggi. 
Budaya lokal di Desa Kayeli dan di Desa Waimiting yang sudah dijelaskan sebelumnya dapat menjadi rekomendasi untuk menjadi salah satu titik pengembangan pariwisata budaya (etnowisata) di Kabupaten Buru karena dalam penjelasan tiap ranah atau jenis budaya lokal di atas memiliki nilai-nilai ekowisata yang dapat diimplementasikan untuk pengembangan pariwisata di Kabupaten Buru. Berikut ini nilai-nilai ekowisata budaya lokal di Desa Kayeli dan Desa Waimiting:

\section{1) Mengandung pilar Environmental Responsibility}

Environmental Responsibility merupakan proteksi, konservasi atau perluasan sumber daya alam serta lingkungan fisik untuk menjamin kehidupan panjang dan keberlanjutan sistem dan tradisi, serta aktivitas yang berkearifan lokal di tengahtengah masyarakat. Kearifan lokal masyarakat di Desa Kayeli dan di Desa Waimiting dengan beragam kekhasan tradisi dalam setiap aktivitas secara tidak langsung memiliki nilai ekonomis untuk menuju ke arah konservasi dan proteksi. Sumber daya alam, sistem kekerabatan, sistem kemasyarakatan, serta kesenian, dan lingkungan fisik yang dimiliki oleh tiap desa tersebut menandakan dan menambah khasanah tradisi di Kabupaten Buru.

\section{2) Pilar Local Economy Vitality}

Local Economy Vitality, yakni menyorong bertumbuhnya dan berkembangnya ekonomi lokal, bisnis serta himpunan atau komunitas demi memenuhi daya kuat ekonomi yang berkelanjutan (sustainability) seperti efek dari pembangunan lokasi wisata akan diikuti oleh ramainya aktivitas ekonomi lokal.

\section{3) Pilar Cultural Sensitivity}

Cultural Sensitivity, yakni mendorong munculnya apresiasi serta penghormatan pada suatu tradisi, kebiasaan/adat istiadat, serta keanekaragaman budaya demi memenuhi keberlangsungan kultur lokal yang baik seperti lewat wisata budaya atau etnowisata, orang akan mengenal budaya daerah dan menimbulkan adanya sikap apresiasi terhadap kekayaan budaya tersebut.

\section{4) Pilar Experiaental Richness}

Experiaental Richness, yakni menciptakan atraksi atau berbagai tradisi yang dapat memperkaya dan meningkatkan pengalaman yang lebih memuaskan melalui partisipatif aktif dalam memahami masyarakat, hubungan masyarakat dengan lingkungan, kebiasaan masyarakat dalam setiap aktivitasnya, serta keterlibatan masyarakat dengan alam.

\section{Penutup}

Bertolak dari hasil penelitian sebelumnya, maka dapat disimpulkan beberapa hal yang menjadi temuan dalam penelitian ini terkait nilai-nilai budaya lokal apa yang mendukung pengembangan pariwisata di Kabupaten Buru dan implementasi nilai budaya lokal dalam mendukung pengembangan pariwisata di Kabupaten Buru.

Nilai-nilai budaya lokal apa yang mendukung pengembangan pariwisata di Kabupaten Buru, yakni dari sistem kepercayaan masyarakat, sistem kemayarakatan, sistem kekerabatan, sistem teknologi, sistem pengetahuan, sistem mata pencaharian, bahasa, serta kesenian, upadara adat, dan pantang larang. 
Dari beberapa unsur-unsur budaya tersebut lahir nilai atau norma tata laku yang berkearifan lokal dalam masyarakat seperti perilaku (tingkah laku) spritual, perilaku ekonomi, perilaku seni, perilaku politik, serta perilaku lain dalam kehidupan dan benda-benda sebagai kesatuan material.

Implementasi nilai budaya lokal dalam mendukung pengembangan pariwisata di Kabupaten Buru mencakup empat pilar, yakni Mengandung pilar Environmental Responsibility, yakni proteksi, konservasi atau perluasan sumber daya alam serta lingkungan fisik; Local Economy Vitality, yakni mendorong tumbuh dan berkembangnya ekonomi lokal, bisnis serta komunitas untuk menjamin kekuatan ekonomi dan berkelanjutan (sustainability); Cultural Sensitivity, yakni mendorong timbulnya penghormatan dan apresiasi terhadap tradisi, adat istiadat, serta keragaman buadaya untuk menjamin keberlangsungan budaya lokal; Experiaental Richness, yakni menciptakan atraksi atau berbagai tradisi yang dapat memperkaya dan meningkatkan pengalaman.

\section{Ucapan Terimakasih}

Dalam kesempatan ini, peneliti menghaturkan banyak terimakasih kepada LLDikti wilayah XII atas kepercayaannya memberikan dana hibah dalam pelaksanaan penelitian ini. Taklupa pula peneliti mengucapkan rasa syukur dan terimakasih atas bentuk dukungan dan fasilitas yang diberikan oleh Kepala Yayasan Muslim Buru, Rektor dan LPPM Universitas lqra Buru sehingga penelitian ini dapat terselesaikan tepat pada waktunya.

\section{Daftar Pustaka}

Departemen Pendidikan Nasional. (2014). Kamus Besar Bahasa Indonesia (IV). Gramedia Pustaka Utama.

Haryanto, J. T. (2013). Implementasi Nilai-nilai Budaya, Sosial, dan Lingkungan Pengembangan Desa Wisata di Provinsi Yogyakarta. Kawistara, 3(1), 1-11.

Istiqomah, E. (2014). Nilai Budaya Masyarakat Banjar Kalimantan Selatan: Studi Indigenous. Psokologi Teori dan Terapan, 5(1), 1-6.

Kuntowijoyo. (2006). Budaya dan Masyarakat (Paripurna). Tiara Wacana.

Kurniawan, W. (2015). Dampak Sosial Ekonomi Pembangunan Pariwisata Umbul Sidomukti Kecamatan Bahdungan Kabupaten Semarang (Laporan Pn). Universitas Negeri Semarang.

Mansyur, F. A., \& Suherman, L. A. (2020). The Function of Proverbs as Educational Media: Anthropological Linguistics on Wolio Proverbs. ELS Journal on Interdisciplinary Studies in Humanities, 3(2), 271-286.

Nurdin, U. (2002). Konteks Implementasi Berbasis Kurikulum. CV Sinar Baru.

Peraturan Pemerintah Republik Indonesia Nomor 50. (2011). Tentang Rencana Induk Pembangunan Kepariwisataan Nasional Tahun 2010-2025.

Rahman, F., \& Letlora, P. S. (2018). Cultural Preservation: Rediscovering the Endangered Oral Tradition of Maluku (A Case Study on Kapata of Central Maluku). Advances in language and literary studies, 9(2), 91-97.

Sahib, H., Rahman, F., Duli, A., \& Asba, A. R. (2019, May). Customary Forest Conservation through Informal Knowledge System of Ammatowa Community. 
In IOP Conference Series: Earth and Environmental Science (Vol. 270, No. 1, p. 012042). IOP Publishing.

Suherman, L. A. (2018). The Analysis of Metaphorical Domain on English "Stab Verb" in Corpora. ELS Journal on Interdisciplinary Studies in Humanities, 1(1), 52-58.

Susiati, S. (2018a). Homonim bahasa kepulauan tukang besi dialek kaledupa di kabupaten wakatobi [the homonymon of tukang besi island languange in kaledupa dialect at wakatobi regency]. Totobuang, 6(1), 109, 123.

Susiati, S. (2018b). Nilai Budaya Suku Bajo Sampela Dalam Film The Mirror Never Lies Karya Kamila Andini [The Cultural Values of The Bajo Sampela Ethnic Group in The Mirror Never Lies Film by Kamila Andini]. Totobuang, 6(2), 297,311.

Susiati, S. R. I. (2018). Kajian Geografi Bahasa dan Dialek di Sulawesi Tenggara: Analisis Dialektometri. Gramatika: Jurnal IImiah Kebahasaan dan Kesastraan, $6(2)$,

https://www.researchgate.net/publication/329895845_Kajian_Geografi_Bahas a_dan_Dialek_di_Sulawesi_Tenggara_Analisis_Dialektometri

Wahab, S. A. (2001). Analisis Kebijaksanaan dari Formula ke Implementasi Kebijaksanaan Negara (Edisi Kedu). Bumi Aksara.

Wahid, A. (2015). Strategi Pengembangan Wisata Nusa Tenggara Barat Menuju Destinasi Utama Wisata Islami (Skripsi). Universitas Muhammadiyah Yogyakarta: Fakultas Ekonomi.

Wiranata, I. G. A. B. (2002). Antropologi Budaya. PT Citra Aditya Bakti. 